\title{
Vitamin D: metamorphosis from nutrient to hormonal system
}

\section{By S. W. Standury, Department of Medicine, University of Manchester, The Royal Infirmary, Manchester}

In so far as a vitamin is regarded as an essential nutrient, 'vitamin D' cannot be assigned that function, although it can acquire the role when social and economic factors pervert the normal physiological means of its provision. The natural vitamin, cholecalciferol (vitamin $\mathrm{D}_{3}$ ), is biologically inert and must undergo successive enzymatic hydroxylations, at $\mathrm{C}-25$ in the liver and at $\mathrm{C}-\mathrm{I}$ in the kidney, to produce the effector molecule, I,25-dihydroxycholecalciferol $\left(1,25-(\mathrm{OH})_{2} \mathrm{D}_{3}\right.$; Fraser, 1980 ). Ergocalciferol (vitamin $\mathrm{D}_{2}$ ), which is obtained exclusively from the diet, is similarly converted to its 1,25 -dihydroxy derivative; it is probably as active as cholecalciferol in man but not in all animal species. The physiological source of 'vitamin D' is the cholecalciferol produced photochemically in the epidermis from the pro-vitamin, 7-dehydrocholesterol (Holick et al. 1977). The term calciferol is used to refer to either cholecalciferol or ergocalciferol and, when referring to the mixed metabolites of these two forms in plasma, the abbreviations $25-(\mathrm{OH}) \mathrm{D}$ and I,25- $(\mathrm{OH})_{2} \mathrm{D}$ are used. The abbreviations $25-(\mathrm{OH}) \mathrm{D}_{3}$ and $\mathrm{I}, 25-(\mathrm{OH})_{2} \mathrm{D}_{3}$ imply a known derivation from cholecalciferol. Although most vertebrates can probably absorb and utilize orally administered calciferols, the sun is the principal source of 'vitamin $D^{\prime}$ ' in man, even in northern climes and in countries practising the fortification of foodstuffs (Haddad \& Hahn, 1973; Preece et al. 1975; Poskitt et al. 1979). The foetus and the neonate, unexposed to ultraviolet irradiation, are dependent on maternal supply. Breast milk contains a water-soluble, sulphate ester of cholecalciferol (Sahashi et al. 1969) and there is indirect evidence that this material is absorbed and utilized by the suckling (Le Boulch et al. 1979; Noff \& Edelstein, 1978). It is present in high concentration in human milk, especially in the early days of lactation (Lakdawala \& Widdowson, 1977), and its excretion by this route may constitute a significant drain on maternal resources. The foetus receives cholecalciferol and 25 -hydroxycholecalciferol $\left(25-(\mathrm{OH}) \mathrm{D}_{3}\right)$ by placental transfer (Haddad et al. 197I; Hillman \& Haddad, I974). There is little transfer of $1,25-(\mathrm{OH})_{2} \mathrm{D}_{3}$ from mother to foetus in the rat (Noff \& Edelstein, 1978), and in the human baby the concentration of $1,25-(\mathrm{OH})_{2} \mathrm{D}$ in the placental venous blood is significantly lower than in the maternal blood (Steichen et al. 1980) but ovine placenta is reported as freely permeable to $\mathrm{I}, 25-(\mathrm{OH})_{2} \mathrm{D}_{3}$ (Ross et al. 1979).

Although it has long been known that cholecalciferol is produced in the epidermis by the action of u.v. irradiation on 7 -dehydrocholesterol, it has only recently been proved that, as in vitro, the photochemical reaction is restricted to the production of pre-cholecalciferol (Holick et al. 1977). The subsequent slow isomerization of pre-cholecalciferol to cholecalciferol is temperature dependent, the equilibrium being about $80 \%$ in favour of cholecalciferol at $37^{\circ}$ and less at lower temperatures. This thermal equilibrium might alone affect the availability of 
cholecalciferol to cold-blooded animals at low environmental temperatures, but there is grafted onto it a biological factor that may have more general relevance. Cholecalciferol, as well as its principal metabolites, is carried in the blood in association with a specific 'vitamin D binding' $\alpha$-globulin (DBP); the affinity of cholecalciferol for DBP is at least $10^{3}$ times greater than of pre-cholecalciferol (Holick et al. 1979). Thus the selective binding of cholecalciferol to DBP and its removal into the circulation would disturb the pre-cholecalciferol-cholecalciferol equilibrium prevailing in skin at any particular temperature and determine the slowly progressive utilization of the initial product of u.v. irradiation. In this sense both molecules could be regarded as an epidermal store of 'vitamin D', available for days or perhaps weeks after cessation of irradiation.

\section{Vitamin $D$ in man}

In man, we have shown that the fractional conversion of cholecalciferol to 25$(\mathrm{OH}) \mathrm{D}_{3}$ is most efficient when the circulating concentration of the former is low (Mawer, 1980) and have suggested that cholecalciferol entering the blood slowly from the skin may be cleared quantitatively by 25 -hydroxylation in the liver (Stanbury et al. 1980). Compatible with this proposal, a subcutaneous or intramuscular depot of radioisotopically labelled cholecalciferol can produce a slowly progressive increase in radioactive plasma $25-(\mathrm{OH}) \mathrm{D}_{3}$ to reach a concentration about twenty-five times that of its precursor, radioactive plasma cholecalciferol (Davies \& Mawer, 1979). There are, as yet, few available measurements of plasma calciferol in man; in Canadian adults in winter, a mean total plasma calciferol of $2 \cdot 2 \mu \mathrm{g} / 1(5 \cdot 7 \mathrm{nmol} / \mathrm{l})$ was associated with a mean total plasma $25-(\mathrm{OH}) \mathrm{D}$ of $16 \mu \mathrm{g} / 1$ (40 nmol/1) (Jones, 1978). Davie \& Lawson (1980) have estimated the cutaneous production of cholecalciferol following a total of 15 min u.v. irradiation of restricted areas of human skin over a period of $17 \mathrm{~d}$. On the basis of the measured increment of plasma $25-(\mathrm{OH}) \mathrm{D}$ in the subjects irradiated, they calculate an epidermal production of cholecalciferol of $0.024 \mathrm{nmol} / \mathrm{cm}^{2}$. It is evident, however, that prolonged irradiation of the whole body can cause a significant increase of circulating cholecalciferol (Davie \& Lawson, r980) and plasma concentrations as high as $12-52 \mu \mathrm{g} / 1(3 \mathrm{I}-\mathrm{I} 35 \mathrm{nmol} / \mathrm{l})$ have been recorded after 3-5 weeks treatment by u.v. irradiation of patients with psoriasis (Bjorkhem et al. 1979). The subsequent fate of such circulating cholecalciferol after cessation of irradiation is unknown but, judging from studies of injected radioactive cholecalciferol, it is to be expected that it will disappear rapidly from the blood (Mawer et al. 1971) by partition into fat and binding to tissue proteins (Mawer et al. 1972).

Under ordinary conditions of living, when most of the body is clothed and solar exposure is episodic, the principal molecular form of 'vitamin D' in blood is not cholecalciferol but ${ }_{25}-(\mathrm{OH}) \mathrm{D}_{3}$ bound to $\mathrm{DBP}$. The binding protein is present in great excess and the plasma concentration of free $25-(\mathrm{OH}) \mathrm{D}_{3}$ is negligible (Bouillon \& Van Baelen, I979). This and its prolonged survival in the blood (half-life 12-30 d; Mawer et al. 197I) makes 25- $(\mathrm{OH}) \mathrm{D}_{3}$ an ideal, and probably inert, 
storage form of the vitamin. DBP also penetrates into most nucleated cells, where it associates with a cytosol protein (Haddad \& Walgate, 1976); since the volume of distribution of $25-(\mathrm{OH}) \mathrm{D}_{3}$ is far greater than the volume of the plasma (Mawer et al. 1972; Gray et al. 1974), it is reasonable to infer that there is free exchange between extracellular and intracellular pools of bound $25-(\mathrm{OH}) \mathrm{D}_{3}$. Although there is speculation that the intracellular $25-(\mathrm{OH}) \mathrm{D}_{3}$ may subserve some specific function(s), this is unproved and it is probably simplest to regard it as part of the bodily store of 'vitamin $\mathrm{D}$ ', of which the plasma $25^{-}(\mathrm{OH}) \mathrm{D}$ is the most easily measured index.

When cholecalciferol enters the blood rapidly, as after its intravenous injection (Mawer, 1980) but also after a single oral dose (Thompson et al. 1966), its concentration in plasma increases greatly. In both circumstances, about $80 \%$ of the absorbed dose is lost from the blood by uptake into tissues (Mawer et al. 1972; Krawitt et al. 1977) and there is a rapid increase of plasma $25-(\mathrm{OH}) \mathrm{D}_{3}$ which reaches its maximum concentration within $\mathrm{I}-3 \mathrm{~d}$. This contrasts with events seen with a slow delivery of cholecalciferol into the blood, when utilization of cholecalciferol appears to be effectively complete and the resulting increase of plasma $25-(\mathrm{OH}) \mathrm{D}_{3}$ reaches its maximum after a matter of weeks (Davies \& Mawer, 1979). Oral pulse dosage with calciferol will thus result in an unphysiological, iatrogenic or factitious storage pool in the tissues, especially fat. This mechanism may serve to limit the potential toxic effects of high therapeutic oral dosage but it cannot be assumed that the tissue depot is readily available. It is possible to cure the clinical effects of vitamin $\mathrm{D}$ deficiency in the British immigrant Asian population with daily single doses of $45^{\circ}$ IU (I I $25 \mu \mathrm{g}$ ) or even $200 \mathrm{IU}(5 \mu \mathrm{g})$ of calciferol (Stanbury et al. 1975, 1981); this suggests that no more than $1 \mu \mathrm{g} / \mathrm{d}$ retained in the metabolic pool may be adequate to correct the deficiency. Yet, on withdrawing such therapy, biochemical relapse within weeks is a commonplace. Thus the cumulative 'store', resulting from sequestration in the tissues of $80 \%$ of each daily dose, appears to be of limited availability to the circulation when treatment is stopped. There is, however, some indirect evidence that the calciferol in fat may become available when fat is mobilized in the course of weight reduction (Connors et al. 1976). It must be emphasized that these remarks on the disposition of an oral dose refer to pulse dosage such as is used therapeutically. It is conceivable that calciferol ingested as a constituent of food is absorbed more slowly, with a lesser rise in its plasma concentration and its consequential more complete utilization. No observations are available on the metabolism of calciferol ingested as food.

\section{Vitamin $D$ requirements}

Orally administered calciferol, perhaps even in a daily dose as low as $2.5 \mu \mathrm{g}$ (100 IU), can provide the bodily requirement; but this means of provision is effective only so long as oral intake is continued, and dosage of this magnitude produces barely detectable increases of plasma $25-(\mathrm{OH}) \mathrm{D}$. Casual solar exposure of uncovered areas of skin during the summer months may increase the mean 
concentration of plasma $25-(\mathrm{OH}) \mathrm{D}$ by $10 \mu \mathrm{g} / 1(25 \mathrm{nmol} / \mathrm{l})$ or more above the winter mean; the concentration in the individual in winter is determined by the level attained in summer (Lawson et al. 1979). In individuals receiving any exposure to effective sunshine, the diet makes a negligible contribution to the total 25- $(\mathrm{OH}) \mathrm{D}$ in plasma. Despite this, even in subjects with low estimated dietary vitamin $\mathrm{D}(0.8-2 \cdot 3 \mu \mathrm{g} / \mathrm{d})$, a significant correlation has been found between plasma 25-(OH)D and intake (Hunt et al. 1976). The plasma 25-(OH)D increases progressively as the daily oral intake is increased from micrograms to milligrams and, at the latter level of dosage, concentrations as high as $500-800 \mu \mathrm{g} / 1$ $\left(1 \cdot 25^{-2} \mathrm{mmol} / \mathrm{l}\right)$ can be attained. Throughout that range of dosage, the relationship between daily intake and plasma $25-(\mathrm{OH}) \mathrm{D}$ is best described by a power function (Stamp et al. 1977). Similarly, following increasing intravenous doses of cholecalciferol, the resulting increment of plasma $25-(\mathrm{OH}) \mathrm{D}_{3}$ is a power function of the induced increase of plasma cholecalciferol (Mawer, I980; Stanbury et al. 1980). Such observations and collateral studies of the control of $25-(\mathrm{OH}) \mathrm{D}_{3}$ production by the isolated perfused liver (Mawer \& Reeve, 1977) have led to the suggestion that the presence of significant concentrations of cholecalciferol in the circulation or in the liver exerts a constraint on quantitative 25 -hydroxylation (Stanbury et al. 1980). When high oral dosage is continued, this constraint is inadequate to prevent the development of concentrations of plasma $25-(\mathrm{OH}) \mathrm{D}$ that can be directly toxic, probably because the concentration of unbound $25-(\mathrm{OH}) \mathrm{D}$ increases rapidly when the total plasma concentration exceeds $100 \mu \mathrm{g} / 1$ $\left(25^{\circ} \mathrm{nmol} / \mathrm{l}\right.$ ) (Bouillon \& Van Baelen, 1979). It is consequently of particular importance that, after months of whole body exposure to summer sunshine, the plasma $25-(\mathrm{OH}) \mathrm{D}$ in man appears not to exceed a maximum concentration of about $80 \mu \mathrm{g} / \mathrm{l}(200 \mathrm{nmol} / \mathrm{l})$ (Haddad \& Chyu, 1971). This can only imply that the delivery of cholecalciferol from skin to liver is limited and, as yet, the mechanism of this limitation is a matter of speculation (Davie \& Lawson, 1980; Stanbury et al. I980). Effectively, the epidermis functions as an endocrine organ that utilizes the energy of u.v. light to produce its secretion, cholecalciferol; and that integrates with the liver to produce a circulating storage form or pro-hormone $\left(25-(\mathrm{OH}) \mathrm{D}_{3}\right)$, of prolonged half-life, in quantities that avoid the causation of intoxication from solar exposure.

\section{Biological activity of vitamin $D$ in health and disease}

Although the point is debated, it is probable that $25-(\mathrm{OH}) \mathrm{D}_{3}$ is inert biologically at physiological concentrations. Its primary function is to act as precursor for the renal production of the hormonal form, $1,25-(\mathrm{OH})_{2} \mathrm{D}_{3}$. This highly potent renal metabolite is active in picomolar concentrations and it is the effector molecule responsible for the expression of most, if not all, the biological effects of the 'vitamin'. In healthy, 'vitamin D' replete individuals its concentration in plasma is maintained within relatively narrow limits $(33 \mathrm{ng} / \mathrm{l}$, SD 6 , or approximately roo pmol/1; Haussler et al. 1976) at a level about I/500 that of plasma $25-(\mathrm{OH}) \mathrm{D}$ but largely independently of the latter. Ostensibly, therefore, measurement of plasma 
$25-(\mathrm{OH}) \mathrm{D}$ should provide an index of the bodily reserve of pro-hormone, and measurement of plasma $1,25-(\mathrm{OH})_{2} \mathrm{D}$ an index of prevailing biological action. Generally this is true but the production of $1,25-(\mathrm{OH})_{2} \mathrm{D}_{3}$ varies with contemporary needs; its renal synthesis is regulated, principally by the parathyroid glands, in response to a primary change of plasma calcium (Fraser, I980). The plasma $1,25-(\mathrm{OH})_{2} \mathrm{D}$ is elevated above the 'normal range' in response to the requirements of mammalian pregnancy and lactation (Kumar et al. 1979; Boass et al. 1977) of avian egg production (Kenney, I976) and when the intake of $\mathrm{Ca}$ is reduced; conversely, it is reduced if the plasma $\mathrm{Ca}$ is raised or the dietary intake of $\mathrm{Ca}$ is abnormally high (Adams et al. 1979). There is also evidence that the activity of the renal 25-hydroxycholecalciferol-la-hydroxylase may be influenced, directly or indirectly, by prolactin (Spanos et al. 1976), growth hormone (Spanos et al. I978), oestrogens (Kenney, I976), adrenal glucocorticoids (Lukert et al. 1976) and probably also by placental lactogen and insulin. Consequently, even in health, the level of plasma $1,25-(\mathrm{OH})_{2} \mathrm{D}$ can be interpreted only in terms of the plane of mineral nutrition and the prevailing physiological state, from the neonatal period, through growth to maturity, pregnancy, lactation etc.

In disease, interpretation may be complicated by structural or functional abnormalities in the kidneys or parathyroid glands, or by reduced sensitivity of its target tissues to $1,25-(\mathrm{OH})_{2} \mathrm{D}_{3}$. The plasma $1,25-(\mathrm{OH})_{2} \mathrm{D}$ may be low, in association with normal or elevated plasma $25-(\mathrm{OH}) \mathrm{D}$, in destructive renal disease, in renal intoxication with lead (Rosen et al. I980) or cadmium (personal observations), or with a genetically determined defect of renal 25hydroxycholecalciferol-l $\alpha$-hydroxylase activity ('vitamin D dependency' (type I); Scriver et al. 1978). In an exceptionally rare disease ('vitamin D dependency' (type 2); Marx et al. 1978) active rickets is associated with greatly increased concentrations of plasma $1,25-(\mathrm{OH})_{2} \mathrm{D}$ and reduced tissue response to its actions. In privational, 'vitamin D-deficiency' rickets or osteomalacia, plasma concentrations of both $25-(\mathrm{OH}) \mathrm{D}$ and $\mathrm{I}, 25-(\mathrm{OH})_{2} \mathrm{D}$ may be appropriately low or unmeasurable; but small oral doses of calciferol can produce a rapid increase of plasma 1,25$(\mathrm{OH})_{2} \mathrm{D}$ to supranormal levels without necessarily inducing a significant increase of plasma $25-(\mathrm{OH}) \mathrm{D}$ (Stanbury et al. 198I). Consequently, in a patient with the clinical features of privational rickets or osteomalacia, the plasma $1,25-(\mathrm{OH})_{2} \mathrm{D}$ can be low, normal or very high.

The assay for plasma $25-(\mathrm{OH}) \mathrm{D}$ in general use does not discriminate between $25-(\mathrm{OH}) \mathrm{D}_{3}$ and $25-(\mathrm{OH}) \mathrm{D}_{2}$ and it provides an integrated measure of reserves acquired from endogenous and exogenous sources. It has proved invaluable in studies of populations in which solar exposure and dietary intake are both marginal or inadequate, and in which there is a significant incidence of osteomalacia. Such populations at risk include the indigenous elderly, both those living at home (Lawson et al. 1979) and especially patients in long-stay geriatric hospitals (Corless et al. 1975), and the children and adult women of the immigrant Asian population (Holmes et al. 1973; Preece et al. 1973). In these individuals, the diet may provide no more than I $\mu \mathrm{g} \mathrm{calciferol/d;} \mathrm{the} \mathrm{hospitalized} \mathrm{patients} \mathrm{may} \mathrm{get} \mathrm{no}$ 
exposure to u.v. light and this is limited in the Asian by social customs. In both groups, the mean plasma $25-(\mathrm{OH}) \mathrm{D}$ and its seasonal variation are less than in the general population and concentrations less than $4 \mu \mathrm{g} / 1$ (10 nmol/l) are common. This is in the range of concentrations at which rickets and osteomalacia are encountered clinically, but the presence of active bone disease cannot be equated with any absolute concentration of plasma $25-(\mathrm{OH}) \mathrm{D}$. It is an unresolved question as to how, when and why particular individuals among a deprived population develop complicating bone disease. It is believed by some workers that the alternative metabolites of $25-(\mathrm{OH}) \mathrm{D}_{3}, 24,25$-dihydroxycholecalciferol (Ornoy $e t$ al. 1978) and 25,26-dihydroxycholecalciferol (Miravet et al. 1976 ) or even $25-(\mathrm{OH}) \mathrm{D}_{3}$ itself, play an essential role in the mineralization of bone. If this were the case, the plasma $25-(\mathrm{OH}) \mathrm{D}$ should provide a predictable index of the development of bone disease, since the formation of both these dihydroxylated metabolites is a direct function of the prevailing concentration of plasma 25-(OH)D (Taylor et al. 1976; Stanbury \& Mawer, 1980). In man, the present evidence suggests that no molecular form other than $1,25-(\mathrm{OH})_{2} \mathrm{D}$ is required for the mineralization of bone (Stanbury et al. 198I). The collateral problem of prophylaxis in populations at risk has a hypothetically simple solution; all it requires is that the individual receives an exposure to summer sunshine no greater than is received by the average active member of the community. In default of the passive therapy of gardening or a daily walk in the sun, exposure to artificial sources of u.v. irradiation has proved effective in geriatric patients in hospital (Corless et al. 1978). In most of those at risk, it may be necessary to resort to the fortification of food or the provision of an oral supplement: even the old-fashioned 'stosstherapie', given as an intramuscular dose of $2.5 \mathrm{mg}$ ergocalciferol, increases plasma $25-(\mathrm{OH}) \mathrm{D}$ in a manner closely resembling that produced by irradiation and maintains its concentration at satisfactory levels for 3 months or more (Davies \& Mawer, 1979).

Cited Departmental researches were supported by a Programme Grant from the Medical Research Council.

\section{REFERENCES}

Adams, N. C., Gray, R. W. \& Lemann, J. Jr. (I979). F. clin. Endocr. Metab. 48, 1008. Bjorkhem, I., Holmbeg, I., Kristiansen, R., Larsson, A. \& Pedersen, J. I. (1979). In Vitamin D: Basic Research and its Clinical Applications, p. 183 [A. W. Norman, editor]. Berlin: de Gruyter.

Boass, A., Toverud, S. A., McCain, T. A., Pike, J. W. \& Haussler, M. R. (1977). Nature, Lond. 267,630 .

Bouillon, R. \& Van Baelen, H. (1979). In Vitamin D: Basic Research and its Clinical Application, p. 137 [A. W. Norman, editor]. Berlin: de Gruyter.

Connors, L. R., Sheikholislam, B. M. \& Irias, J. J. (1976). Pediatrics, Springfield 57, 794.

Corless, D., Beer, M., Boucher, J., Gupta, S. P. \& Cohen, R. D. (1975). Lancet i, 1404.

Corless, D., Gupta, S. P., Switala, S., Barragry, J. M., Boucher, B. J., Cohen, R. D. \& Diffey, B. L. (I978). Lancet ii, 649 .

Davie, M. \& Lawson, D. E. M. (I980). Clin. Sci. 58, 235.

Davies, M. \& Mawer, E. B. (1979). In Vitamin D: Basic Research and its Clinical Application, p. 609 [A. W. Norman, editor]. Berlin: de Gruyter. 
Fraser, D. (1980). Physiol. Rev. 60, 551 .

Gray, R. W., Weber, H. P., Dominghez, J. H. \& Lemann, J. Jr. (1974). F. clin. Endocr. Metab. 39, 1045 .

Haddad, J. G., Boisseau, V. \& Avioli, L. V. (1971). F. lab. clin. Med. 77, 908.

Haddad, J. G. \& Chyu, K. J. (1971). F. clin. Endocr. Metab. 33, 992.

Haddad, J. G. \& Hahn, T. J. (1973). Nature, Lond. 244, 1973.

Haddad, J. G. \& Walgate, J. (I976). F. biol. Chem. 25x, 4803 .

Haussler, M. R., Baylink, D. J., Hughes, M. R., Brumbaugh, P. F., Wergedal, J. E., Shen, F. H., Nielsen, R. L., Counts, S. J., Bursac, K. M. \& McCain, T. A. (1976). Clin. Endocr. 5 (Suppl. I5), IS.

Hillman, L. S. \& Haddad, J. G. (1974). F. Pediat. 84, 742.

Holick, M. F., Frommer, J. E., McNeill, S. C., Richtand, N. M., Henly, J. W. \& Potts, J. T. Jr. (I977). Biochem. biophys. Res. Commun. 76, 107.

Holick, M. F., Holick, S. A., McNeill, S. M., Richtand, N., Clark, M. B. \& Potts, J. T. Jr. (1979). In Vitamin D: Basic Research and its Clinical Application, p. 173 [A. W. Norman, editor]. Berlin: de Gruyter.

Holmes, A. M., Enoch, B. A., Taylor, J. L. \& Jones, M. E. (1973). Q. $\mathfrak{l l}$ Med. 42, 125.

Hunt, S. P., O'Riordan, J. L. H., Windo, J. \& Truswell, A. S. (I976). Br. med. F. 2, I35I.

Jones, G. (1978). Clin. Chem. 24, 287.

Kenney, A. D. (1976). Am. F. Physiol. 230, 1609.

Krawitt, E. L., Grundman, M. J. \& Mawer, E. B. (1977). Lancet ii, 1246.

Kumar, R., Cohen, W. R., Silva, P. \& Epstein, F. H. (1979). F. clin. Invest. 63, 342.

Lakdawala, D. R. \& Widdowson, E. M. (1977). Lancet i, 167.

Lawson, D. E. M., Paul, A. E., Black, A. E., Cole, T. J., Mandal, A. R. \& Davie, M. (1979). Br. med. F. 2, 303 .

Le Boulch, N., Laromiguière, M., Marnay-Gulat, C., Miravet, L. \& Raoul, Y. (1979). In Vitamin D: Basic Research and its Clinical Application, p. 85 [A. W. Norman, editor]. Berlin: de Gruyter.

Lukert, B. P., Stanbury, S. W. \& Mawer, E. B. (1976). Endocrinol. 93, 718.

Marx, S. J., Spiegel, A. M., Brown, E. M., Gardner, D. G., Downs, R. W. Jr., Attie, M., Hamstra, A. J. \& DeLuca, H. F. (1978). F. clin. Endocr. Metab. 47, 1303.

Mawer, E. B. (1980). In Vitamin D: Molecular Biology and Clinical Nutrition, p. 149 [A. W. Norman, editor]. New York: Dekker.

Mawer, E. B., Backhouse, J., Holman, C. A., Lumb, G. A. \& Stanbury, S. W. (1972). Clin. Sci. 43,413 .

Mawer, E. B., Lumb, G. A., Schaefer, K. \& Stanbury, S. W. (1971). Clin. Sci. 40, 39.

Mawer, E. B. \& Reeve, A. (I977). Calcif. Tissue Res. 22 (suppl.), 24.

Miravet, L., Redel, J., Carre, M., Queillé, M. L. \& Bordier, P. (1976). Calcif. Tissue Res. 21, I 45.

Noff, D. \& Edelstein, S. (1978). Hormone Res. 9, 292.

Ornoy, A., Goodwin, D., Noff, D. \& Edelstein, S. (1978). Nature, Lond. 276, $5^{1} 7$.

Poskitt, M. E., Cole, T. J. \& Lawson, D. E. M. (1979). Br. med. F. 1, 221.

Preece, M. A., Ford, J. A., McIntosh, W. B., Dunnigan, M. G., Tomlinson, S. \& O'Riordan, J. L. H. (1973). Lancet i, 907.

Preece, M. A., Tomlinson, S., Ribot, C. A., Pietrek, J., Korn, H. T., Davies, D. M., Ford, J. A., Dunnigan, M. G. \& O'Riordan, J. L. H. (1975). Q. fl Med. 44, 575.

Rosen, J. F., Chesney, R. W., Hamstra, A., DeLuca, H. F. \& Mahaffey, K. R. (Ig80). New Engl. F. Med. 302, I 128.

Ross, R., Care, A. D., Taylor, C. M., Pelc, B. \& Sommerville, B. A. (1979). In Vitamin D: Basic Research and its Clinical Application, p. 34I [A. W. Norman, editor]. Berlin: de Gruyter.

Sahashi, Y., Suzuki, T., Higaki, M. \& Asano, T. (1969). f. Vitamin, fapan 15, 78.

Scriver, C. R., Reade, T. M., DeLuca, H. F. \& Hamstra, A. J. (1978). New Engl. Y. Med. 299, 976,

Spanos, E., Barrett, D., MacIntyre, I., Pike, J. W., Saflilian, E. \& Haussler, M. R. (1978). Nature, Lond. 273, 246.

Spanos, E., Pike, J. W., Haussler, M. R., Colstron, K. W., Evans, I. M. A., Goldner, A. M., McCain, T. A. \& MacIntyre, I. (1976). Life Sciences 19, 175 I.

Stamp, T. C. B., Haddad, J. G. \& Twigg, C. A. (1977). Lancet i, 1341.

Stanbury, S. W. \& Mawer, E. B. (I980). Clin. Sci. 58, $5^{23}$. 
Stanbury, S. W., Mawer, E. B., Taylor, C. M. \& de Silva, P. (1980). Mineral Electrolyte Metab. 3, 5 I.

Stanbury, S. W., Taylor, C. M., Lumb, G. A., Mawer, E. B., Berry, J., Hann, J. \& Wallace, J. (1981). Mineral Electrolyte Metab. (In the Press).

Stanbury, S. W., Torkington, P., Lumb, G. A., Adams, P. H., de Silva, P. \& Taylor, C. M. (1975). Proc. Nutr. Soc. 34, I I I.

Steichen, J. J., Tsang, R. C., Gratton, T. L., Hamstra, A. \& De Luca, H. F. (1980). New Engl. f. Med. 302, 31 5 .

Taylor, C. M., Hughes, S. E. \& de Silva, P. (1976). Biochem. biophys. Res. Commun. 70, 1243.

Thompson, G. R., Lewis, B. \& Booth, C. C. (Ig66). F. clin. Invest. 45, 94. 